\title{
Exceptionally preserved insect fossils in the Late Jurassic lagoon of Orbagnoux (Rhône Valley, France)
}

The Late Kimmeridgian marine limestones of the area around Orbagnoux (Rhône, France) are well known for their fish fauna and terrestrial flora. Here we record the first insects and their activities (mines on leaves and trails in sediments) from these layers, including the oldest record of the gerromorphan bugs, as a new genus and species Gallomesovelia grioti, attributed to the most basal family Mesoveliidae and subfamily Madeoveliinae. These new fossils suggest the presence of a complex terrestrial palaeoecosystem on emerged lands near the lagoon where the limestones were deposited. The exquisite state of preservation of these fossils also suggests that these outcrops can potentially become an important Konservat-Lagerstätte for the Late Jurassic of Western Europe. 
1 Exceptionally preserved insect fossils in a the Late Jurassic lagoon of Orbagnoux (Rhône Valley,

2 France)

3 André $\mathrm{Nel}^{1 *}$, Patricia Nel${ }^{1}$, Régis Krieg-Jacquier ${ }^{2}$, Jean-Marc Pouillon ${ }^{3}$ and Romain Garrouste ${ }^{1 *}$

$4 \quad{ }^{1}$ Muséum National d'Histoire Naturelle, Institut de Systématique, Evolution, Biodiversité,

5 ISYEB, UMR 7205 CNRS UPMC EPHE, CP50, 45 rue Buffon, F-75005 Paris, France; e-mails:

6 anel@mnhn.fr, pnel@mnhn.fr, garroust@mnhn.fr,

$7 \quad 218$ rue de la Maconne, F-73000 Barberaz, e-mail: regis.krieg.jacquier@gmail.com

$8 \quad 3178$ rue des Plattieres, F-38300 Nivolas Vermelle, France, e-mail: jmpdb@wanadoo.fr

9 ABSTRACT

10 The Late Kimmeridgian marine limestones of the area around Orbagnoux (Rhône, France) are

11 well known for their fish fauna and terrestrial flora. Here we record the first insects and their

12 activities (mines on leaves and trails in sediments) from these layers, including the oldest record

13 of the gerromorphan bugs, as a new genus and species Gallomesovelia grioti, attributed to the

14 most basal family Mesoveliidae and subfamily Madeoveliinae. These new fossils suggest the

15 presence of a complex terrestrial palaeoecosystem on emerged lands near the lagoon where the

16 limestones were deposited. The exquisite state of preservation of these fossils also suggests that

17 these outcrops can potentially become an important Konservat-Lagerstätte for the Late Jurassic of

18 Western Europe.

19 Subjects Entomology, Paleontology 
Keywords Insecta, Heteroptera, Mesoveliidae, gen. et sp. nov., attacks on Zamites leaves, trails

21 in sediment.

22

23

24

25

\section{INTRODUCTION}

Tithonian Konservat-Lagerstätte of lithographic limestone of Bavaria is well known with the numerous discoveries of emblematic fossils (Archaeopteryx, etc.) (Schweigert, 2007), clearly less fossils were obtained from the French Late Kimmeridgian equivalents of these rocks in the departments of Ain and Rhône. Only the lithographic limestone formation of Cerin has been the subject of significant scientific studies on taphonomy, flora, and ichnofossils (Bernier et al., 1991, 2014). The fauna is essentially of marine origin (Wenz et al., 1994; Gaillard et al., 2006) if the presence of vertebrate trackways demonstrates that some terrestrial environments were very close to this place. Neither insect nor trace was discovered at Cerin, unlike the rich palaeoentomofauna of the lithographic limestone of Bavaria (Carpenter, 1992). The sites around Orbagnoux were better candidates for the discovery of terrestrial arthropods because fossil plants are more frequent and well preserved than in other places like Cerin (Barale, 1981). However, early exploration of this area during the $19^{\text {th }}$ and $20^{\text {th }}$ century contributed to our knowledge on Jurassic fossils but no new studies have been carried out in more recent times.

During two field works during 2012 and 2013, with the help of the Société des Naturalistes et Archéologues de l'Ain and the Groupe 'Sympetrum' (Recherche et Protection des Libellules), we could discover in the outcrops around Orbagnoux a small bug that represents the first Late Jurassic insect of France, plus insect-mediated plant damages, and probably track ways of aquatic fly larvae. These first discoveries suggest that more terrestrial arthropods might be present in these layers, although these fossils seem to have been washed in the lagoonal environment. Also the quality of preservation of these fossils is better than those of the fossil 
insects from the Bavarian lithographic limestone, suggesting that Orbagnoux can become one of the major insect outcrops for the Late Jurassic.

\section{MATERIAL AND METHODS}

The fossils were collected in the small valley of the river Dorches (a river Rhône tributary), situated on the territory of the Corbonod village, North West of Orbagnoux mine (Long. $5^{\circ} 46^{\prime}$ 32.2" E, Lat. $45^{\circ} 59^{\prime} 26.3^{\prime \prime} \mathrm{N}$, alt. $597 \mathrm{~m}$ ), and in the newly recorded outcrop of the "Croix de Famban" (situated along the small road D123, alt. 1310-1313 m, Long. $5^{\circ} 45^{\prime} 58.5^{\prime}$ E, Lat. $45^{\circ}$ $56^{\prime} 58.9^{\prime \prime} \mathrm{N}$, and along the eastern margin of the anticlinal surface, $200 \mathrm{~m}$ south of the road), situated south-west of Orbagnoux, in lithographic and bituminous limestones of the same horizon (see Figure 1). These levels are raised and follow the anticlinal of le Grand Colombier situated west parallel to the Rhône valley between Corbonod and Songieu (Gudefin, 1968). Tribovillard et al. (1999) considered that this formation is very poor in macroorganisms ("quasi-abiotic platy limestone accumulation"). The highly bituminous black shales inside of the Orbagnoux mine (Chateauneuf et al., 1982) contain few macrofossils (personal observations): mainly rather poorly preserved ammonites and bivalves, foraminifers and ostracods). On the contrary, fossil plants, fishes and crustaceans are known in other layers outside of the mine (Barale, 1981; Tejo Yuwono, 1987) (see Figure 2). More precisely, plants remains (leaves, fruit cones, seeds, branches, pollen) are very frequent in the less bituminous dark brown levels outside of the mine in the Dorches valley. The flora yielded almost 34 species which belong to plant groups quite well known from the Jurassic: Pterydophytes, Pteridospermales, Cycadales, Ginkgoales, Bennetitales, and Coniferales (Barale, 1981). The most frequent leaves correspond to bennetitalian foliage type Zamites sp. Fossil fishes (Sauvage, 1893; Wenz et al., 1994), vertebrate coprolites, crustaceans, oysters, small ammonite shells and aptychi (Enay et al., 1994) can be found in yellow lithographic layers situated three meters above the plant layers (Barale et al., 1992). An insect 
has been found in the same yellow lithographic layers; it is described below. On the contrary the animals seem to be quite rare in the plant layers. A second small outcrop is situated $30 \mathrm{~m}$ (alt. 657 $\mathrm{m}$, along a small forest road) south of the main one. It is very rich in plant remains, some with insect attacks, described below. The new outcrop of the "Croix de Famban" (unrecorded in Barale, 1981) has given also thick layers rich of large leaves of Zamites and delicate laminites with small fishes, crustaceans, and traces of animal activities in the sediment (some being herein attributed to fly larvae).

These lithographic and bituminous limestones (Late Kimmeridgian "calcaire en plaquettes" Formation) correspond to a marine shallow lagoonal environment. The formation of these carbonate deposits are due to the developments of microbial mats ("kopara" Tribovillard et al., 1999, 2000). These authors indicated that the palaeoenvironment corresponds to a lagoon delimited by a reef barrier and to islands occupied by terrestrial organisms (plants and animals) coming into the lagoon. Some insects (fly larvae) could apparently live in the shallow brackish sediments (see below).

Specimen examinations have been made with an Olympus microscope SZX9 and drawings made with a drawing tube. Environmental SEM images have been made with Tescan Vega II LSU in variable pressure mode (SE, secondary electron).

The electronic version of this article in Portable Document Format (PDF) will represent a published work according to the International Commission on Zoological Nomenclature (ICZN), and hence the new names contained in the electronic version are effectively published under that Code from the electronic edition alone. This published work and the nomenclatural acts it contains have been registered in ZooBank, the online registration system for the ICZN. The ZooBank LSIDs (Life Science Identifiers) can be resolved and the associated information viewed through any standard web browser by appending the LSID to the prefix "http://zoobank.org/". The LSID for this publication is: urn:lsid:zoobank.org:pub:8154DAD2-355D-4591-A4FC- 
92 7E6EFC95B368. The online version of this work is archived and available from the following

93 digital repositories: PeerJ, PubMed Central and CLOCKSS.

94 SYSTEMATIC PALEONTOLOGY

95 1. Adult insect from Orbagnoux

96 Infraorder Gerromorpha Popov, 1971

97 Family Mesoveliidae Douglas and Scott, 1867

98 Subfamily Madeoveliinae Poisson, 1959

99 Included genera. Modern Madeovelia Poisson, 1959 and Mesoveloidea Hungerford, 1929, 100 Gallomesovelia gen. nov.

101 Genus Gallomesovelia gen. nov.

102 Type species. Gallomesovelia grioti sp. nov.

103 Diagnosis. Adult macropterous characters. Large size (body $6.0 \mathrm{~mm}$ long); large rounded eyes;

104 tegmen covered with setae; abdominal sternite 8 similar to sternite 7.

105 Etymology. Named after Gallia, ancient Latin name for France, and Mesovelia. Gender feminine.

106 Gallomesovelia grioti sp. nov.

107 (Figure 3)

108 Material. Holotype specimen MNHN.F.A51098 (print and counterprint of a nearly complete bug,

109 fossilised in lateral view, legs and antennae not preserved).

110 Diagnosis. As for the genus

111 Etymology. Named after our friend and colleague Claire Griot, who rendered possible the field 112 researches around Orbagnoux outcrop. 
113 Remark. A rather large (ca. $6 \mathrm{~cm}$ long) shrimp is fossilised in the piece of rock $0.5 \mathrm{~mm}$ (three

114 laminae) below the print of this bug. It was first detected by the presence of a depression in the

115 sediment and is only evident on the x-radiograph (see Figure 4).

116 Description. Body $6.0 \mathrm{~mm}$ long; with wings and thorax covered with a distinct pile of microsetae;

117 head $0.75 \mathrm{~mm}$ long, $0.87 \mathrm{~mm}$ high, deflected in front of eyes but without transverse constriction;

118 compound eye rather large, rounded, $0.35 \mathrm{~mm}$ diameter; no ocelli; cephalic trichobothria not

119 preserved; insertion of antenna visible below eye; labium elongate, reaching level of mid coxae,

120 four-segmented, with segments 1 and 2 very short, segment 3 very long, $1.32 \mathrm{~mm}$ long, much

121 longer than segment 4, $0.37 \mathrm{~mm}$ long; no pair of bucculae covering base of labium; thorax 2.2

$122 \mathrm{~mm}$ long; prothorax $0.62 \mathrm{~mm}$ long $3.8 \mathrm{~mm}$ high, with a suture separating tergum and

123 sternopleuron; pronotum short; mesoscutellum triangular exposed, $0.5 \mathrm{~mm}$ long; a small

124 metanotal elevation; forewing $3.6 \mathrm{~mm}$ long, covered with microsetae, lacking claval commissure

125 but with two basal cells and one apical cell and a "pterostigma"-like broadening of vein Sc+R

126 (subcosta+radius); coxae inserted close to ventral midline of thorax, all oriented obliquely

127 backward (especially for the posterior ones), distance between fore and mid coxae $0.54 \mathrm{~mm}$,

128 between mid and hind coxae $1.0 \mathrm{~mm}$; abdomen $3.1 \mathrm{~mm}$ long, ca. $1.7 \mathrm{~mm}$ high, with seven

129 sternites visible laterally, i.e. sternites 2 to 7 plus sternite 8 narrower than other sternites, and not

130 divided in two parts (male).

131 Discussion. This fossil bug falls in the Gerromorpha because of the following characters, after

132 Schuh \& Slater (1995): compound eyes large, rounded; head not constricted transversely;

133 forewing lacking claval commissure, not divided into a corium-clavus-membrane; wings and part

134 of body covered with a distinct pile of microsetae. Unfortunately the cephalic trichobothria,

135 characteristic of the Gerromorpha, are not visible above the eye (Andersen, 1982). An attribution

136 to the subfamily Madeoveliinae would be supported by the following characters: macropterous;

137 mesoscutellum triangular exposed; coxae inserted close to the ventral midline of thorax 
138 (plesiomorphy); no pair of bucculae covering base of labium; ocelli lacking; forewing with two 139 basal cells and one apical cell (Andersen, 1982, 1999; Schuh \& Slater, 1995).

Male genitalia and egg characters, important in the family diagnosis are unfortunately not detected in the type specimen of Gallomesovelia gen. nov. Nevertheless, the mesoscutellum present but relatively reduced and the metanotal elevation, are both apomorphic characters present in Gallomesovelia, the macropterous Mesoveliidae but also in the Hebridae (Damgaard, 2008b: 454).

The attribution of Gallomesovelia to the Madeoveliinae is supported by the following apomorphies (Andersen \& Polhemus, 1980; Andersen, 1999; Damgaard et al., 2012: 193): head deflected in front of eyes; adults macropterous and without ocelli. More precisely, the absence of ocelli supports an attribution to the Madeoveliinae, as the reduction of ocelli in the macropterous morphs is convergent in the Mesoveliidae: Madeoveliinae, the Gerridae, plus some Veliidae and Hydrometridae (Damgaard, 2008b; Damgaard et al., 2012). The two modern madeoveliine genera Madeovelia and Mesoveloidea have the plesiomorphic presence of prothoracic suture separating tergum and sternopleuron (Andersen, 1999: 13; Damgaard et al., 2012: 193). Gallomesovelia has this character too. The shape of the pronotal lobe cannot be determined because of the animal is visible in lateral view; nevertheless, it seems that there is no anterior constriction as in winged Mesoveliinae (Andersen \& Polhemus, 1980). The general shape of body and forewing venation of Gallomesovelia are similar to those of Madeovelia and Mesoveloidea in the large rounded eyes, shape of labium, tegmen covered with setae (Poisson, 1959; Hungerford, 1929; Jaczewski, 1931; Moreira et al., 2006). The main difference of Gallomesovelia with both the male and the female of Mesoveloidea is the abdominal sternite 8 as large and long as sternite 7. A further important difference is the greater size (body $6.0 \mathrm{~mm}$ long in Gallomesovelia instead of $2.9 \mathrm{~mm}$ in Mesoveloidea peruviana Drake, 1949, 2.9 to $3.8 \mathrm{~mm}$ in Mesoveloidea williamsi Hungerford, 1929, and $2.6 \mathrm{~mm}$ in Madeovelia guineensis Poisson, 1959) (Hungerford, 1929; 
Poisson, 1959; Schuh \& Slater, 1995). More generally Gallomesovelia is rather large compared to the modern and fossil Mesoveliidae.

The Mesoveliidae are considered as the sister group to all other Gerromorpha (Damgaard, 2008; Weirauch \& Schuh, 2011; Damgaard et al., 2012), but not the oldest Gerromorpha + Panheteropera known $($ Panheteroptera $=$ Nepomorpha + Leptodomorpha + Cimicomorpha + Pentatomorpha). The oldest known Heteroptera are undescribed Nepomorpha from the Triassic (Late Carnian) of Virginia (Fraser \& Grimaldi, 1999).

Gallomesovelia is the oldest known representative of the superfamily Gerromorpha. Li et al. (2012) placed the gerromorphan radiation during the Jurassic using molecular phylogeny and fossil calibration. Our fossil is congruent with all the current hypotheses.

The Gerridae, Hydrometridae, and Veliidae are known in the Early Cretaceous (Solòrano-Kraemer et al., 2014), while Hebridae are only recorded from the Cenozoic (Damgaard, 2008a). Thus the absence of the Mesoveliidae in the Mesozoic remained surprising. The present discovery confirms the recent attributions of some Cretaceous fossils to this family: the immature gerromorphan nymph from the Mid Cretaceous French amber described by Perrichot et al. (2005) is currently attributed to the Mesoveliidae as one of us (AN) suggested in the first version of the paper of 2005, while two other Mesoveliinae are also newly recorded from the same amber (Solòrano-Kraemer et al., 2014). Nevertheless all the other Mesozoic taxa previously attributed to the Mesoveliidae are currently considered as Heteroptera incertae sedis (Damgaard et al., 2012). The Miocene Mesovelia dominicana Garrouste and Nel, 2010 remains the unique described Cenozoic Mesoveliidae.

\section{Insect herbivory on Zamites leaves}

Although traces of insect herbivory are rather frequent and diverse in the fossil record (Labandeira and Currano, 2013), the Late Jurassic is a period with a relatively poor record of 
such traces, compared to the Triassic or to the end of the Lower Cretaceous (Labandeira, 2006). Therefore any new fossil, like the present discoveries, is welcome. Jud et al. (2010) listed evidences of 'cone boring, anthophily (pollination), pollenivory, wood borings, cortex borings, leaf oviposition, leaf grazing, and leaf galling' but no insect mines on the Mesozoic Bennettitales. Pott et al. (2008) described oviposition damages on foliage from the Upper Triassic of Austria. Pott et al. (2012) and Edirisooriya \& Dharmagunawardhane (2013) described leaf-margin feedings on Middle Jurassic Anomozamites villosus and Otozamites beanie respectively. Schweigert \& Dietl (2010) described rounded structures on Zamites feneonis as "probable prints of former galls" from the Late Kimmeridgian of the Nusplinger lithographic limestone in Germany. Harris (1942) also described galls on the bennettitalean Anomozamites.

The first found fossil (specimen MNHN.F.A51100, A. Nel leg.) is the print and counterprint of a leaf of a Zamites species, $70.0 \mathrm{~mm}$ long, $75.0 \mathrm{~mm}$ wide, with 13 leaflets preserved, with several surface feeding traces. These structures are longitudinally oriented, generally situated along the margins of the leaflets, elongate, $5.0-16.0 \mathrm{~mm}$ long, $2.0-2.5 \mathrm{~mm}$ wide. The sides of the slots are straight and the ends are rounded. Their central parts are devoid of organic matter in the print but the surface of the leaflet cuticle is still present in the counterprint. They are surrounded by a darker zone that corresponds to a rim of reaction tissue $0.5-1.0 \mathrm{~mm}$ wide, darker than the organic matter of the main part of the leaflet (see Figure 5). Except in one case, there is only one attack per leaflet and only seven of the 13 leaflets are attacked.

Two other Zamites leaves with traces of insect activities were found in the collection François Escuillié (Gannat, France), coming from the same outcrop and level (Figure 6). The second specimen is a large leave with all leaflets attacked by insects, some of them covering nearly all the surface of the leaflet. Nevertheless they are identical to the traces on the first leaf (see Figure 5). The third specimen is a unique small hyaline oval trace filled with carbon and looks slightly different from the traces on the first and second specimens. 
Although the leaves of Zamites are very frequent in the outcrop of Orbagnoux, no other

213

214

trace of insect activity was detected among ca. 100 leaves of Zamites we collected there. They can be considered as being rare. No other plant was found attacked.

The evidence from insect interactions with bennettitalian plants from Orbagnoux is completely different from the structures already described on other Zamites leaves, even to those described on some Upper Triassic Zamites from the United States (Ash, 1996: 242, figs 3-4, 2005).

The structures from Orbagnoux could correspond to a surface feeding DT103 “elongate window feeding (sub)parallel to major venation" type (sensu Labandeira et al., 2007), rather than to mining activities as the surface of the leaflet cuticle is preserved at least on one side and no remains of coprolite were found.

The main differences with the damages on Triassic Zamites described by Ash (1996) are as follows: those from Orbagnoux are broader, covering more than two veins of the leaflet; they are situated along the leaflet margin instead of being 1-3 mm from the margins. Thus they were probably caused by different insects. Ash (1996) supposed that the Triassic attacks could have been caused by "grazing insects". It is quite delicate to determine which type of insect could have caused the mines from Orbagnoux. Nevertheless, a holometabolous larva could be responsible of such attacks. Similar attacks are frequent on modern angiosperm leaves, caused by larvae of Diptera, Lepidoptera, or Coleoptera (AN personal observations). Because of the hardness of the Zamites leaflets, it is more likely a beetle larva that could have caused these attacks. These structures are similar to traces produced by modern Chrysomelidae, but the presence of Chrysomelidae during the Jurassic is still debated (compare Gómez-Zurita et al. 2007; Wang et al. 2014).

\section{Sinusoidal trails similar to trace fossil Cochlichnus Hirchock, 1858}


236 These sinusoidal traces of an animal activity were found in thin yellow lithographic laminites in

237 the outcrop of the "Croix de Famban" (specimen MNHN.F.A51099, Figure 7). Small fishes, 238 vertebrate coprolites, worm trails, and crustaceans (isopods and shrimps) are also present in the 239 same layers. Plants are frequent in thicker layers just above these laminites but absent in the 240 laminites. These traces are similar to the modern grazing trails formed by stratiomyid or 241 ceratopogonid fly larvae in shallow freshwater or brackish sediments (Metz, 1987; Mángano et 242 al., 1996). The oldest known Stratiomyidae and Ceratopogonidae are Lower Cretaceous (Huang 243 and Lin, 2007; Borkent et al., 2013). Similar traces in marine environments have been interpreted 244 of worm- or gastropod-origin (Hakes, 1976; Dam, 1990). Together with the other organisms 245 found in this outcrop, they demonstrate that the corresponding palaeoenvironment was clearly not 246 abiotic, as postulated by Tribovillard et al. (1999).

\section{Palaeoenvironmental implications}

The main part of the fauna found in the Late Jurassic layers around Orbagnoux clearly correspond to marine environments (ammonites, bivalvia, shrimps, isopods, fishes, etc.), the present discoveries confirm the presence of a very close terrestrial biota, which was supposed after the presence of a rather diverse flora represented by leaves and reproductive organs (cones). The rarity of insects together with the partly decayed state of the type specimen of Gallomesovelia grioti (legs and antennae missing), suggest a transport of these terrestrial organisms into the marine environment. Modern mesoveliids (water treaders) are predators, and strictly freshwater or terrestrial insects, living in humid places, but some are associated with marine habitats (intertidal). Gallomesovelia grioti could have lived very close to the sea margin or even in the brackish part of the lagoon itself, as some modern Mesoveliidae (Andersen, 1982: 338: fig. 597): it was maybe a surface skater because of the particular orientations of the coxae, directed backwards (Andersen, 1982: 288-289). Due to the preservation of the terrestrial insect 
260 bodies that is generally rather poor in the Bavarian Tithonian (Tischlinger, 2001), it would be 261 nearly impossible to expect to find there such small and delicate insects similar to 262 Gallomesovelia grioti. This situation renders very precious any new discovery of terrestrial 263 arthropods in Orbagnoux outcrops. The discovery of the traces of insect activities on a Zamites 264 leave shows that the diversity of the terrestrial arthropods was probably significant, the insect 265 fauna not being reduced to few aquatic or subaquatic bugs, like in a simple atoll lagoon beaches 266 or beach rock. Nevertheless future investigations shall be necessary to discover the 267 palaeodiversity of this new insect world.

\section{ACKNOWLEDGEMENTS}

269 We thank Vladimir Makarkin and two anonymous referees for their valuable comments on the 270 first version of this paper. We sincerely thank the Société des Mines d'Orbagnoux for the kind 271 authorization to collect fossils in their property. Special thanks to Torsten Wappler for 272 information and references on insect herbivory on Zamites. We also thank a lot the following 273 colleagues for their kind help during the field campaigns in 2012 and 2013: MMr. Bernard 274 Béreyziat, Michel Béreyziat, Guy Robert, Pierre Roncin, Jean-Marie Demaury, Thierry Virton, 275 Bernard Janvier, and Daniel Grand. A special thank to Claire Griot because she rendered possible 276 these investigations, inviting us in her wonderful country and home. Lastly we thank Mr. 277 François Escuillié for the authorization to photograph the specimens in his collection. We thank 278 Sylvain Pont from LMCM lab/ MNHN Direction des collections MEB Service for MEM-EDS 279 Imaging.

REFERENCES

281 Andersen NM. 1982. The semiaquatic bugs (Hemiptera: Gerromorpha): phylogeny, adaptations, 282 biogeography and classification. Entomonograph 3:1-445. 
Andersen NM. 1999. Cryptovelia stysi sp. n. from Borneo with a reanalysis of the phylogeny of the Mesoveliidae (Heteroptera: Gerromorpha). Acta Societatis Zoologicae Bohemicae 63:5-18.

Andersen NM, Polhemus JT. 1980. Four new genera of Mesoveliidae (Hemiptera: Gerromorpha) and the phylogeny and classification of the family. Entomologica Scandinavica 11:369-392.

Ash SR. 1996. Evidence of arthropod-plant interactions in the Upper Triassic of the Southwestern United States. Lethaia 29:237-248.

Ash SR. 2005. Synopsis of the Upper Triassic flora of Petrified Forest National Mark and vicinity. In: Nesbitt SJ, Parker WG, Irmis RB (eds). Guidebook to the Triassic Formations of the Colodaro Plateau in Northern Arizona: Geology, Palaentology, and History. Mesa Southwest Museum, Bulletin 9:53-61.

Barale G. 1981. La paléoflore jurassique du Jura français: étude systématique, aspects stratigraphiques et paléoécologiques. Documents des Laboratoires de Géologie de Lyon 81:1466.

Barale G, Philippe M, Thevenard F. 1992. Locality of Orbagnoux: Gully la Dorche. 4th International Organization of Palaeobotany Conference: 60-69.

Bernier P, Barale G, Bourseau J-P, Buffetaut E, Gaillard C, Gall J-C, Wenz S. 2014. The lithographic limestones of Cerin (southern JuraMountains, France). A synthetic approach and environmental interpretation. C. R. Palevol

Bernier P, Gaillard C, Gall J-P, Barale G, Bourseau J-P, Buffetaut E, Wenz S. 1991. Morphogenetic impact of microbial mats on surface structure of Kimmeridgian micritic limestone (Cerin, France). Sedimentology 38:127-136.

Borkent A, Coram RA, Jarzembowski EA. 2013. The oldest fossil biting midge (Diptera: Ceratopogonidae) from the Purbeck Limestone Group (Lower Cretaceous) of southern Great Britain. Polish Journal of Entomology 82:273-279. 
Carpenter FM. 1992. Superclass Hexapoda. In: Moore, R.C., Kaesler, R.L. (eds). Treatise on Invertebrate Paleontology. The Geological Society of America and the University of Kansas, Boulder, Colorado, (R), Arthropoda 4, 3/4: xxii + 655 pp.

Chateauneuf JJ, Alabouvette B, Cautru JP, Feys R, Glintzboeckel C, Malatrait AM, Marteau, P. 1982. Evaluation des ressouces en schistes bitumineux de la France et esquisse de valorisation. Rapport du Bureau de Recherches Géologiques et Minières, 82 SGN 617 GEO: 202 pp.

Dam G. 1990. Taxonomy of trace fossils from the shallow marine Lower Jurassic Neil Klinter Formation, East Greenland. Bulletin of the Geological Society of Denmark 38:119-144.

Damgaard J. 2008a. Evolution of the semi-aquatic bugs (Hemiptera: Heteroptera: Gerromorpha) with a re-interpretation of the fossil record. Acta Entomologica Musei Nationalis Pragae 48: 251268.

Damgaard J. 2008b. Phylogeny of the semiaquatic bugs (Hemiptera-Heteroptera, Gerromorpha). Insect Systematics \& Evolution 39:431-460.

Damgaard J, Moreira FFF, Hayashi M, Weir TA, Zettel H. 2012. Molecular phylogeny of the pond treaders (Insecta: Hemiptera: Heteroptera: Mesoveliidae), discussion of the fossil record and a checklist of species assigned to the family. Insect Systematics \& Evolution 43:175-212.

Drake CJ. 1949. Two new Mesoveliidae, with check list of American species. Boletín de Entomología Venezolana 7:145-147.

Enay R, Bernier P, Barale G, Bourseau J-P, Buffetaut, E., Gaillard C, Gall J-C, Wenz S. 1994. Les ammonites des calcaires lithographiques de Cerin (Ain, France): stratigraphie et taphonomie. Geobios 27 (Supplement 1):25-36.

Edirisooriya G, Dharmagunawardhane HA. 2013. Plant insect-interactions in Jurassic fossil flora from Sri Lanka. International Journal of Scientific and Research Publications 3:1-12. 
332 Fraser NC, Grimaldi DA. 1999. A significant late Triassic Lagerstätte from Virginia, U.S.A.

333 Rivista del Museo Civico di Scienze Naturale E. Caffi 20:79-84.

334 Gaillard C, Goy J, Bernier P, Bourseau J-P, Gall J-C, Barale G, Buffetaut E, Wenz S. 2006.

335 New jellyfish taxa from the Upper Jurassic lithographic limestones of Cerin (France): taphonomy 336 and ecology. Palaeontology 49:1287-1302.

337 Garrouste R, Nel A. 2010. First semi-aquatic bugs Mesoveliidae and Hebridae (Hemiptera: 338 Heteroptera: Gerromorpha) in Miocene Dominican amber. Insect Systematics \& Evolution 41:93339102.

340 Gómez-Zurita J, Hunt T, Kopliku F, Vogler AP. 2007. Recalibrated tree of leaf beetles 341 (Chrysomelidae) indicates independent diversification of angiosperms and their insect herbivores. $342 \quad$ PLOS ONE 2:1-8.

Gudefin H. 1968. Recherche des causes de la pollution organique constatée dans l'eau 344 d'exhaure de la mine d'Orbagnoux (Ain). Bureau de Recherches Géologiques et Minières, Lyon, 345 février 1968:39 pp.

Hakes WG 1976. Trace fossils and depositional environment of four clastic units, Upper Pennsylvanian megacyclothems, northeast Kansas. The University of Kansas Paleontological Contributions 63:1-60.

Harris TM. 1942. Wonnacottia, a new bennettitalean microsporophyll. Annals of Botany New $350 \quad$ Series 6:577-592.

Huang, D-Y, Lin, Q-B. 2007. A new soldier fly (Diptera, Stratiomyidae) from the Lower 352 Cretaceous of Liaoning Province, northeast China. Cretaceous Research 28:317-321. Hungerford HB. 1929. A new genus of semi-aquatic Hemiptera. Bulletin of the Brooklyn 354 Entomological Society 24:288-290.

355 Jaczewski TL. 1931. The male of Mesoveloidea williamsi Hungerford (Hemiptera: Heteroptera). 356 Proceedings of the Entomological Society of Washington 33:64-66. 
Jud NA, Rothwell GW, Stockey RA. 2010. Paleoecological and phylogenetic implications of Saxicaulis meckertii gen. et sp. nov.: a bennettitalean stem from the Upper Cretaceous of Western North America. International Journal of Plant Science 171:915-925.

Labandeira CC. 2006. The four phases of plant-arthropod associations in deep time. Geologica Acta 4:409-438.

Labandeira CC, Currano E. 2013. The fossil record of plant-insect dynamics. Annual Review of Earth and Planetary Sciences 41:287-311.

Labandeira CC, Wilf P, Johnson KR, Marsh F. 2007. Guide to insect (and other) damage types on compressed plant fossils (Version 3.0 - Spring 2007). Smithsonian Institution, Washington, DC.

Li Min, Tian Ying, Zhao Ying and Bu, Wenjun 2012. Higher level phylogeny and the first divergence time estimation of Heteroptera (Insecta: Hemiptera) based on multiple genes. PLoS One, 7 (2) pe32152:1-17.

Mángano MG, Buatois LA, Claps GL. 1996. Grazing trails formed by soldier fly larvae (Diptera: Stratiomyidae) and their paleoenvironemental and paleoecological implications for the fossil record. Ichnos 4:163-167.

Metz R. 1987. Sinusoidal trail formed by a recent biting midge (family Ceratopogonidae): trace fossil implications. Journal of Paleontology 61:312-314.

Perrichot V, Nel, A, Néraudeau D. 2005. Gerromorphan bugs in Early Cretaceous French amber (Insecta: Heteroptera): first representatives of Gerridae and their phylogenetic and palaeoecological implications. Cretaceous Research 26:793-800.

Poisson RA. 1959. Sur un nouveau représentant africain de la faune terrestre commensale des biotopes hygropétriques: Madeovelia guineensis gen. n., sp. n. (Heteroptera). Bulletin de l'Institut Français d'Afrique Noire (A) 21:658-663. 
Pott C, Labandeira CC, Krings M, Kerp H. 2008. Fossil insect eggs and ovipositional damage on bennettitalean leaf cuticles from the Carnian (Upper Triassic) of Austria. Journal of Paleontology 82:778-789.

Pott C, McLoughlin S, Wu Shinqing, Friis EM. 2012. Trichomes on the leaves of Anomozamites villosus sp. nov. (Bennettitales) from the Daohugou beds (Middle Jurassic), Inner Mongolia, China: mechanical defence against herbivorous arthropods. Review of Palaeobotany and Palynology 169:48-60.

Moreira FFF, Ribeiro JRI, Nessimian JL. 2006. Description of the male and the southernmost record of Mesoveloidea williamsi Hungerford, 1929 (Hemiptera: Heteroptera: Mesoveliidae). Zootaxa 1269:51-56.

Sauvage HE. 1893. Note sur quelques poissons du calcaire bitumineux d'Orbagnoux (Ain). Bulletin de la Société d'Histoire Naturelle d'Autun 6:427-443.

Schuh RT, Slater JA. 1995. True bugs of the World (Hemiptera: Heteroptera). Classification and natural history. Comstock Publishing Associates, Cornell University Press, Ithaca and London: i-xii + 1-336.

Schweigert G. 2007. Ammonite biostratigraphy as a tool for dating Upper Jurassic lithographic limestones from South Germany - first results and open questions. Neues Jahrbuch für Geologie und Paläontologie, Abhandlungen 245:117-125.

Schweigert G, Dietl G. 2010. Miscellanea aus dem Nusplinger Plattenkalk (OberKimmeridgium, Schwäbische Alb). 11. Ein Blattrest mit Abdrücken von Gallen. Jahresberichte und Mitteilungen des Oberrheinischen Geologischen Vereins (N.F.) 92:35-40.

Solòrzano-Kraemer M, Perrichot V, Soriano C, Damgaard J. 2014. Fossil water striders in Cretaceous French amber (Heteroptera: Gerromorpha: Mesoveliidae and Veliidae). Systematic Entomology 39: 590-605. 
Tejo Yuwono N. 1987. Lithostratigraphie, microfacies et analyse de la matière organique des formations géologiques (Kimméridgien à Berriasien du Jura méridional, région de Seyssel, Ain et Haute-Savoie. Thèse Université de Savoie, Chambéry:120 pp.

Tischlinger H. 2001. Bemerkungen zur Insekten-Taphonomie der Solnhofener Plattenkalke. Archaeopteryx 19:29-44.

Tribovillard N, Trichet J, Défarge C, Trentesaux A 1999. Jurassic lagoonal environments and quasi-abiotic platy limestone accumulation: microbial interventions. Sedimentology 46:11831197.

Tribovillard N, Trentesaux A, Trichet J, Défarge C. 2000. A Jurassic counterpart for modern kopara of the Pacific atolls: lagoonal, organic matter-rich, laminated carbonate of Orbagnoux (Jura Mountains, France). Palaeogeography, Palaeoclimatology, Palaeoecology 156:277-288.

Wang B, Ma JY, McKenna DD, Yan EV, Zhang HC, Jarzembowski EA. 2014. The earliest known longhorn beetle (Cerambycidae: Prioninae) and implications for the early evolution of Chrysomeloidea. Journal of Systematic Palaeontology 12:565-574.

Weirauch C, Schuh RT. 2011. Systematics and evolution of Heteroptera: 25 Years of progress. Annual Review of Entomology 56:487-510.

Wenz S, Bernier P, Barale G, Bourseau J-P, Buffetaut E, Gaillard C, Gall J-C. 1994. L'ichthyofaune des calcaires lithographiques du kimméridgien supérieur de Cerin (Ain, France). Geobios 27 (supplément 1):61-70.

\section{Author Contributions}

- André Nel \& Romain Garrouste analyzed the data, wrote the paper, prepared figures, and reviewed drafts of the paper.

- Patricia Nel, Régis Krieg-Jacquier \& Jean-Marc Pouillon participated to the field researches, prepared figures, reviewed drafts of the paper, and contributed with iconography. 
Figure 1. Geographic map with locations of the three concerned outcrops.

430

431

432

433

434

435

436

437

438

439

440

441

442

443

444 with nearly all leaflets attacked (scale bar $2 \mathrm{~cm}$ ), (B) second specimen with only one attack on a

445 leaflet (scale bar $1 \mathrm{~cm})$.

Figure 2. Selected fossil organisms from Orbagnoux outcrop. (A) Brachyphyllum elegans, specimen JMP 455 (coll. J.-M. Pouillon); (B) Pachypterix sp., specimen JMP 391 (coll. J.-M. Pouillon); (C) Leptolepis cf. voithi (coll J.-C. Demaury); (D) Crustacea Penaeidae (coll J.-C. Demaury) (scale bars $10 \mathrm{~mm}$ ).

Figure 3. Aquatic bug from Orbagnoux outcrop: Gallomesovelia grioti sp. nov. (Holotype MNHN.F.A51098). (A) reconstruction; H: head, E: Eye, M: mesonotum, Pr : pronotum, As: abdominal segments $\mathrm{Cx}$ : coxae, Me: metanotum, Mee: metanotum elevation, Wv: wing veins, Gs: genital segment, Pt: pterostigma; (B) photograph without alcohol; (C) photograph under alcohol (scale bars $1 \mathrm{~mm}$ for A, B and C).

Figure 4. Crustacea indet., Malacostraca?. X-ray photograph of a specimen fossilised below holotype of Gallomesovelia grioti (scale bar $10 \mathrm{~mm}$ ).

Figure 5. Insect traces on a Zamites leave (MNHN.F.A51100). (A) print, Orbagnoux outcrop; (B) counterprint (scale bars $10 \mathrm{~mm}$ ).

Figure 6. Insect traces on Zamites leaves, specimens from Escuillié collection. (A) specimen 
446 Figure 7. Sinusoidal trails cf. Cochlichnus (Croix de Famban outcrop, MNHN.F.A51099), (A)

447 print, (B) counterprint (scale bars $10 \mathrm{~mm}$ ). 


\section{Figure 1}

map

Figure 1. Geographic map with locations of the three concerned outcrops.

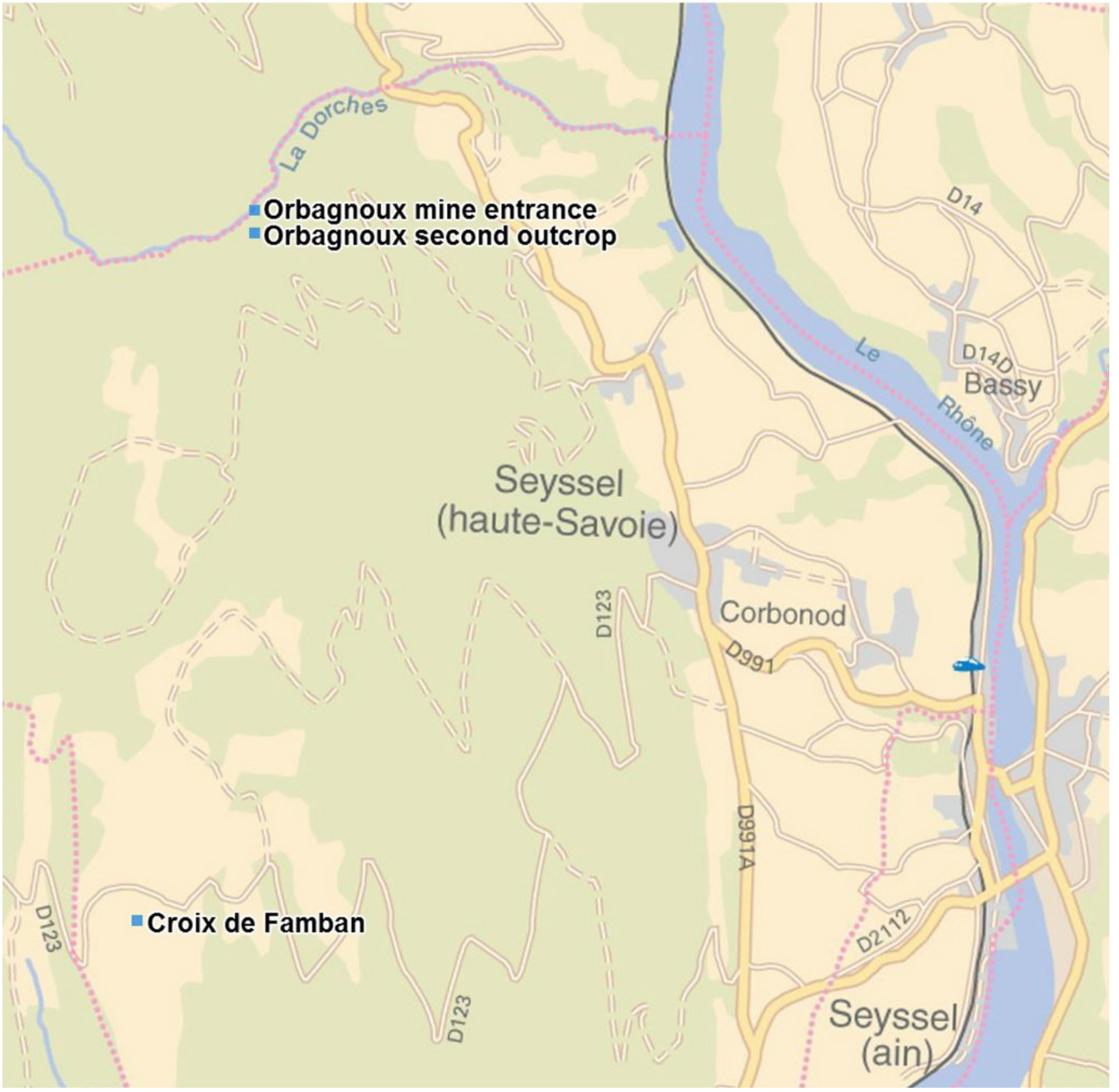




\section{Figure 2}

fauna

Figure 2. Selected fossil organisms from Orbagnoux outcrop. (A) Brachyphyllum elegans, specimen JMP 455 (coll. J.-M. Pouillon); (B) Pachypterix sp., specimen JMP 391 (coll. J.-M. Pouillon); (C) Leptolepis cf. voithi (coll J.-C. Demaury); (D) Crustacea Penaeidae (coll J.-C. Demaury) (scale bars $10 \mathrm{~mm}$ ).
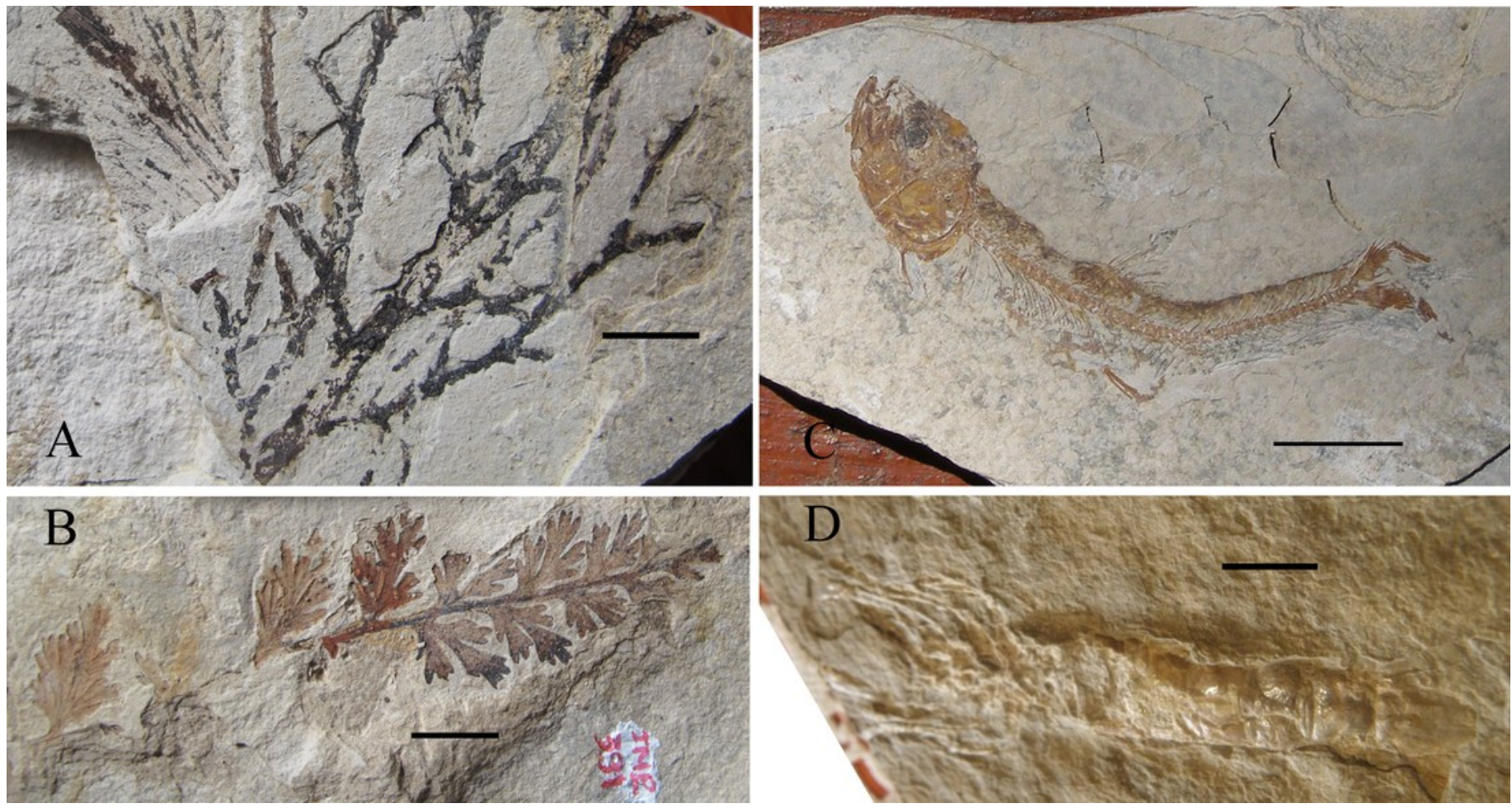


\section{Figure 3}

mesoveliidae

Figure 3. Aquatic bug from Orbagnoux outcrop: Gallomesovelia grioti sp. nov. (Holotype MNHN.F.A51098). (A) reconstruction; H: head, E: Eye, M: mesonotum, Pr : pronotum, As: abdominal segments $\mathrm{Cx}$ : coxae, Me: metanotum, Mee: metanotum elevation, Wv: wing veins, Gs: genital segment, Pt: pterostigma; (B) photograph without alcohol; (C) photograph under alcohol (scale bars $1 \mathrm{~mm}$ for $\mathrm{A}, \mathrm{B}$ and $\mathrm{C}$ ). 

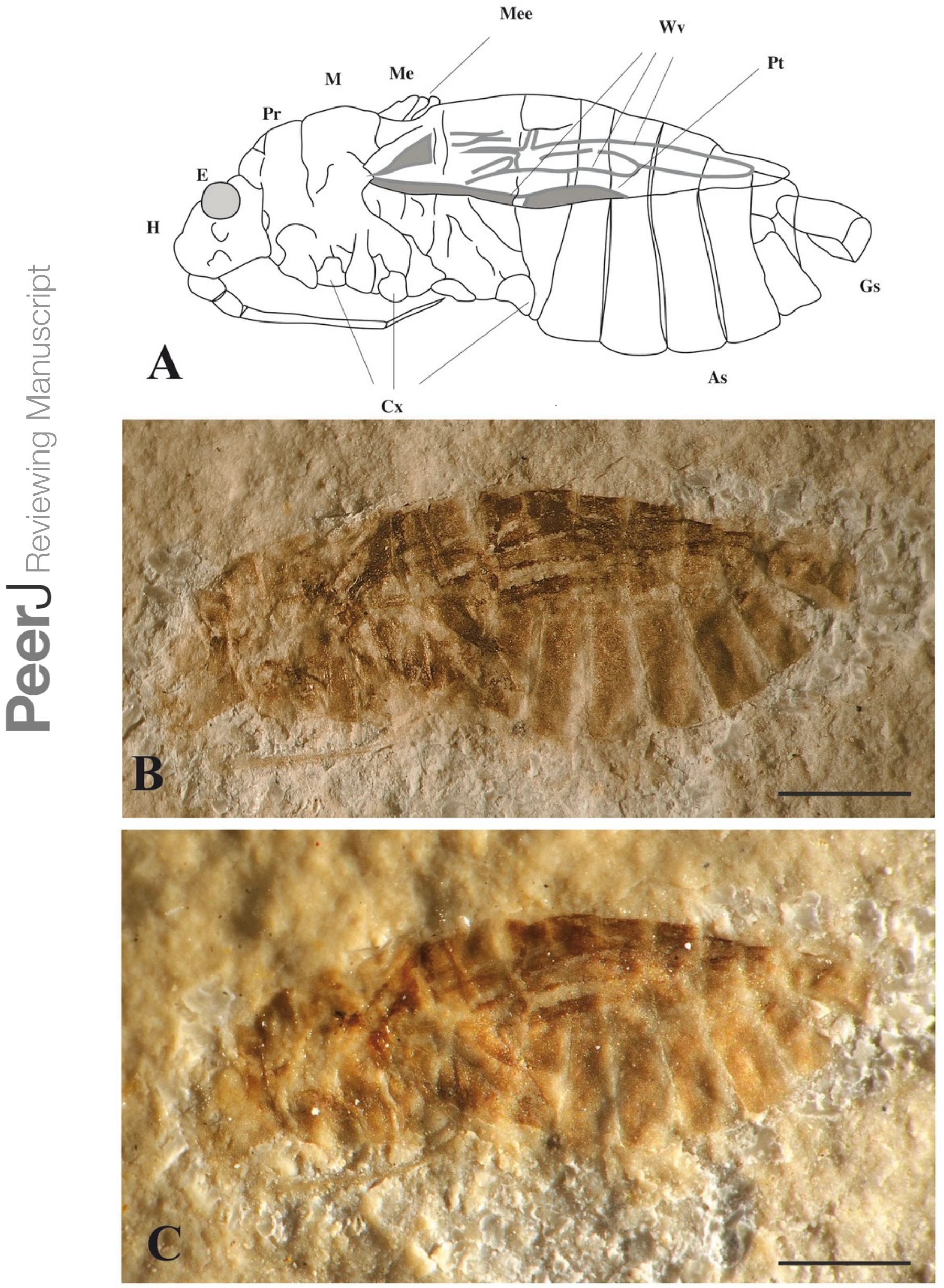


\section{Figure 4}

\section{crustacea}

Figure 4. Crustacea indet., Malacostraca?. X-ray photograph of a specimen fossilised below holotype of Gallomesovelia grioti (scale bar $10 \mathrm{~mm}$ ).

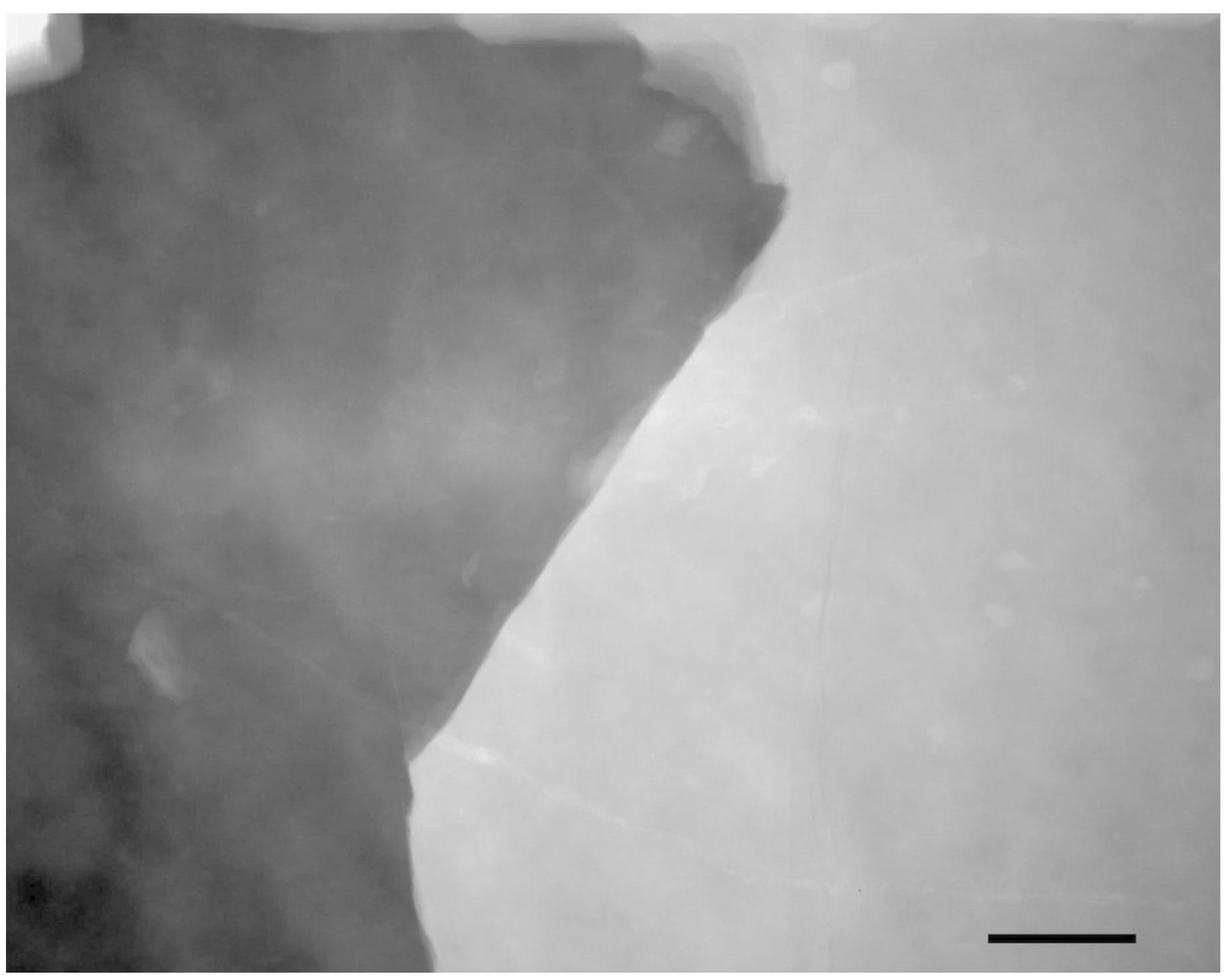




\section{Figure 5}

\section{zamite attack 1}

Figure 5. Insect traces on a Zamites leave (MNHN.F.A51100). (A) print, Orbagnoux outcrop;

(B) counterprint (scale bars $10 \mathrm{~mm}$ ). 


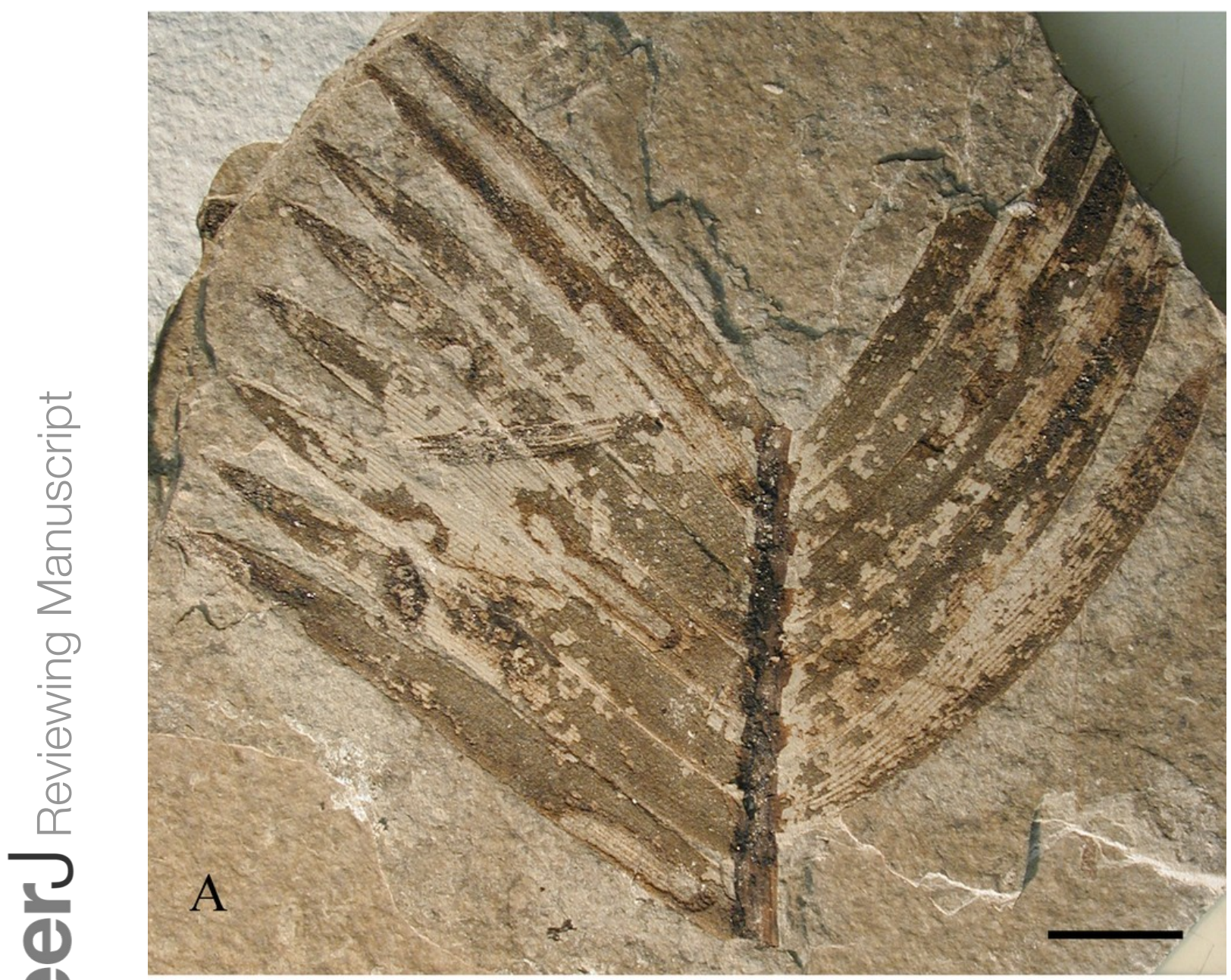

(a)

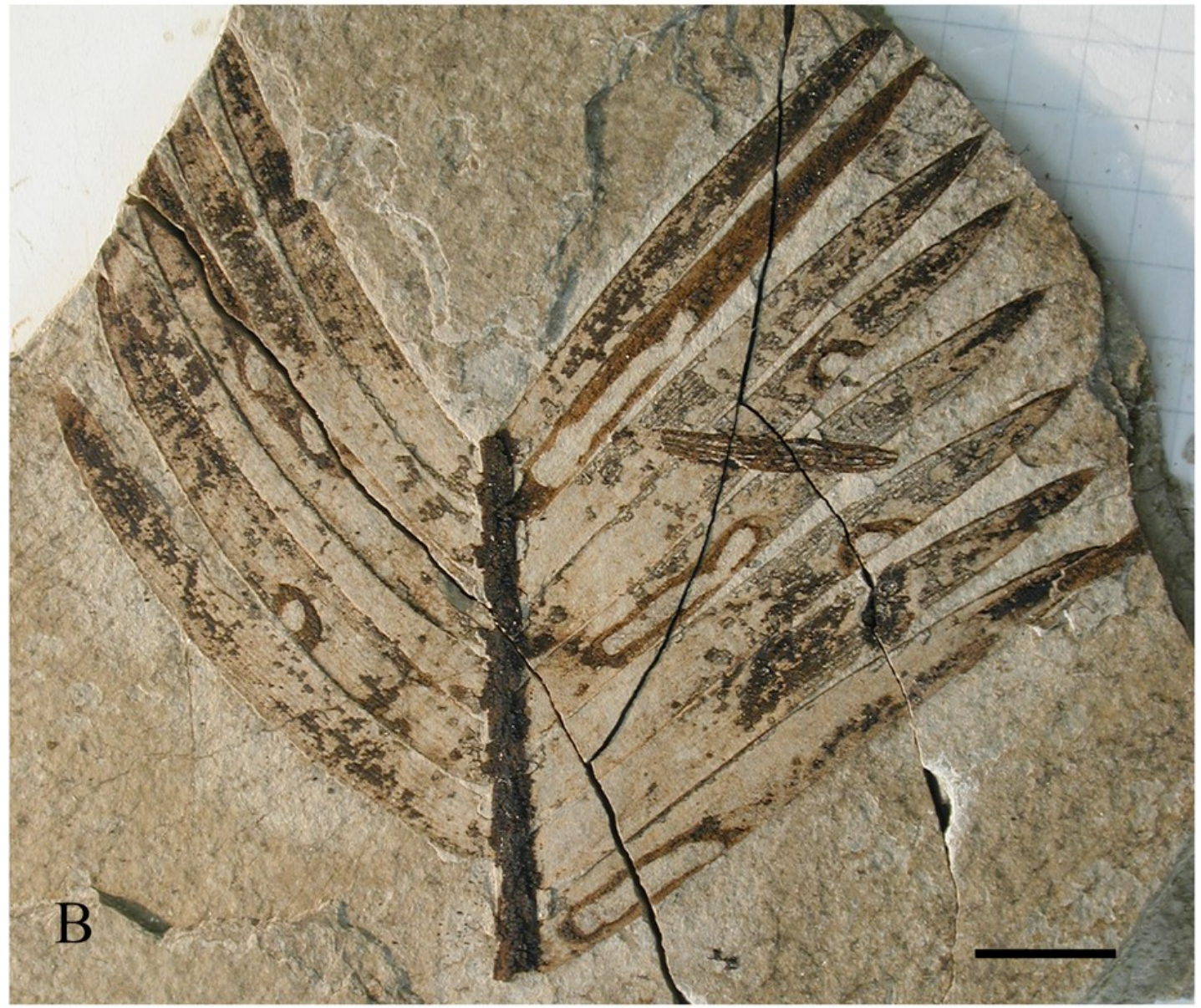

PeerJ reviewing PDF | (v2014:06:2259:1:1:ACCEPTED 16 Jul 2014) 


\section{Figure 6}

\section{zamites attack 2}

Figure 6. Insect traces on Zamites leaves, specimens from Escuillié collection. (A) specimen with nearly all leaflets attacked (scale bar $2 \mathrm{~cm}$ ), (B) second specimen with only one attack on a leaflet (scale bar $1 \mathrm{~cm}$ ). 

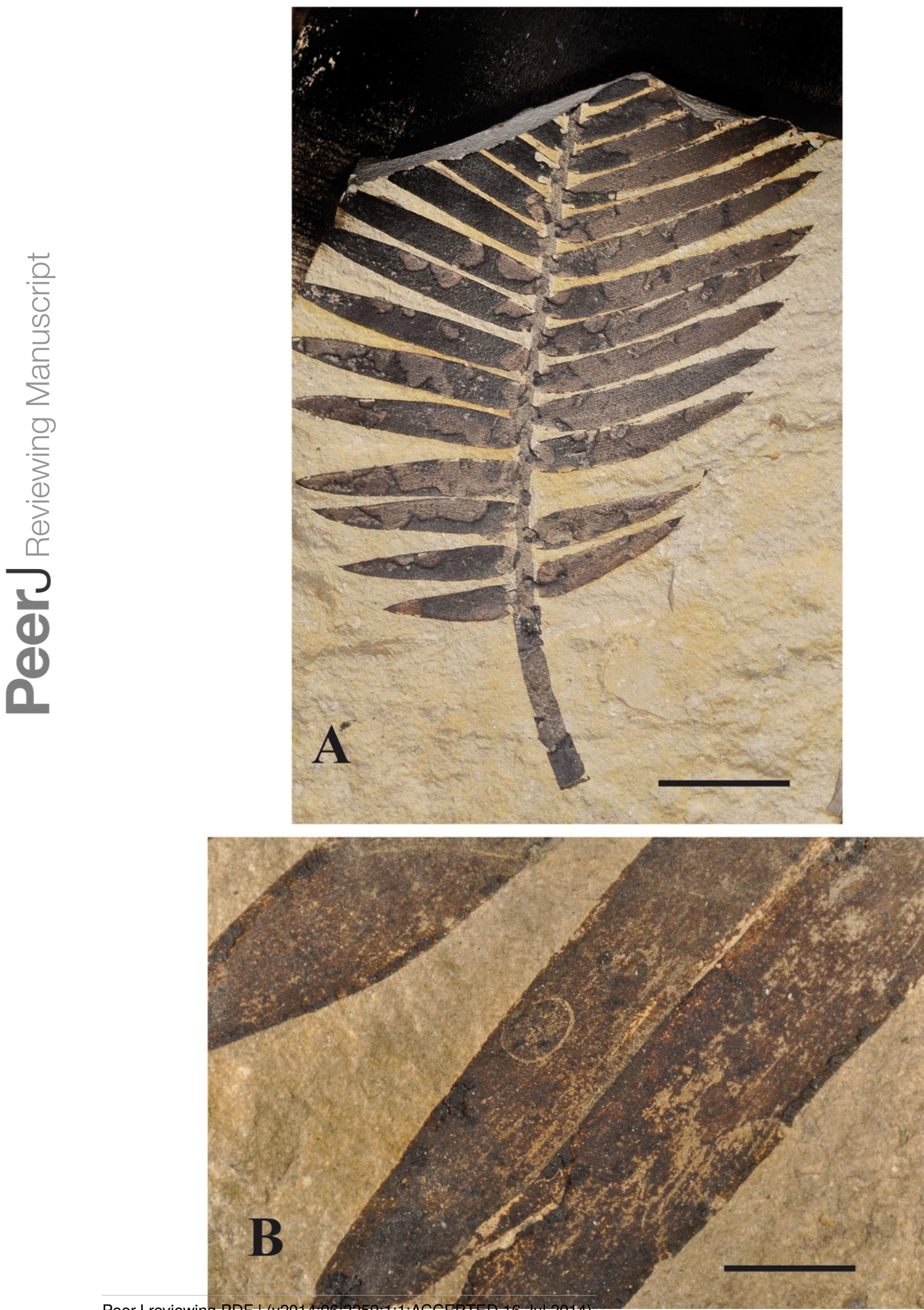


\title{
Figure 7
}

\author{
trackways
}

Figure 7. Sinusoidal trails cf. Cochlichnus (Croix de Famban outcrop, MNHN.F.A51099), (A) print, (B) counterprint (scale bars $10 \mathrm{~mm}$ ).
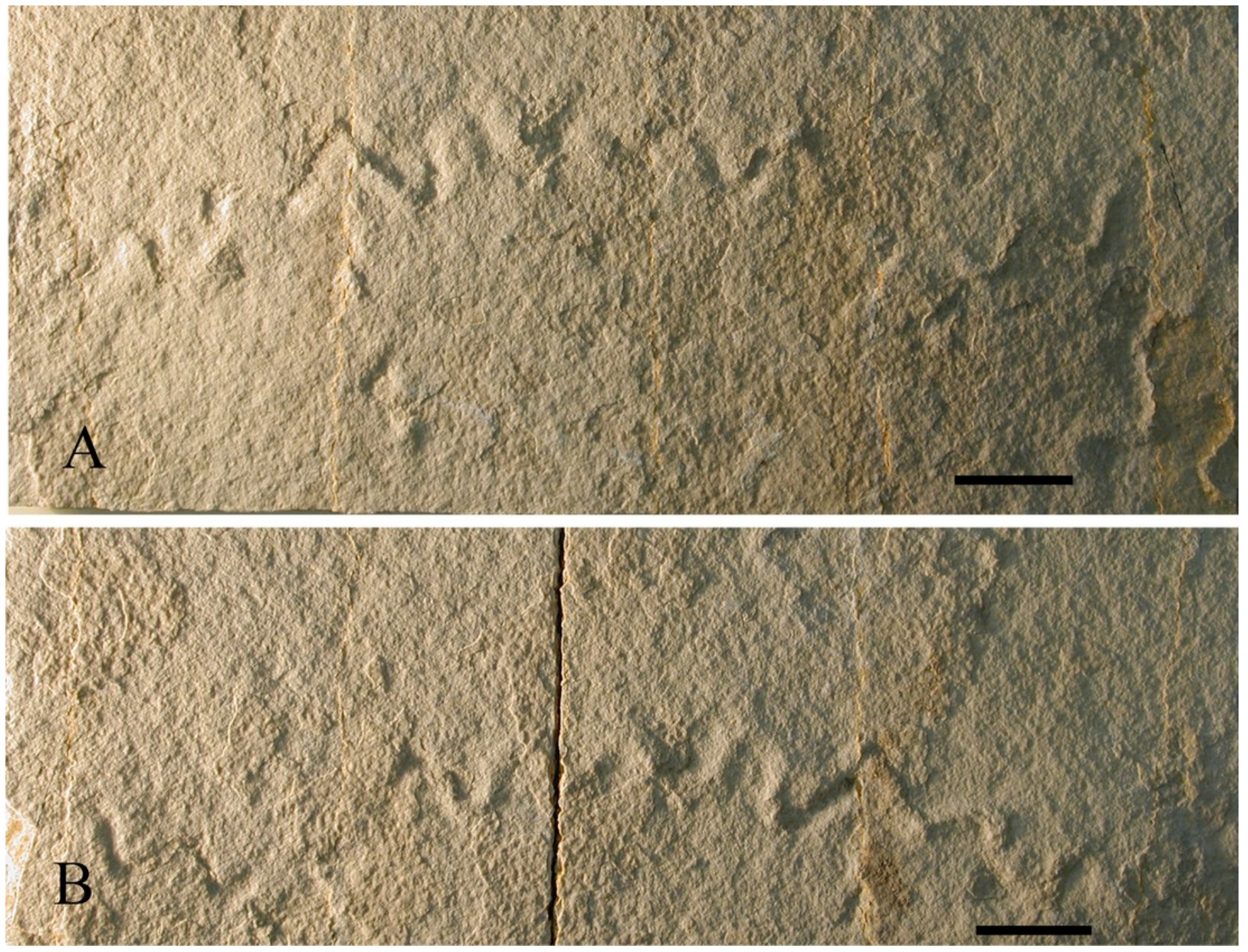